Ambiances

anbiances Environnement sensible, architecture et espace urbain

$7 \mid 2021$

Staging Atmospheres: Theatre and the

Atmospheric Turn - Volume 2

\title{
Staging Atmospheres: Editorial introduction to the second volume
}

Atmosphères en scène: Introduction au deuxième volume

Chloé Déchery and Martin Welton

\section{CpenEdition}

Journals

Electronic version

URL: https://journals.openedition.org/ambiances/3910

DOI: 10.4000/ambiances.3910

ISSN: 2266-839X

Publisher:

Direction Générale des Patrimoines - DAPA - MCC, UMR 1563 - Ambiances Architectures Urbanités (AAU)

Electronic reference

Chloé Déchery and Martin Welton, "Staging Atmospheres: Editorial introduction to the second volume", Ambiances [Online], 7 | 2021, Online since 22 December 2021, connection on 24 December 2021. URL: http://journals.openedition.org/ambiances/3910 ; DOI: https://doi.org/10.4000/ambiances.3910

This text was automatically generated on 24 December 2021.

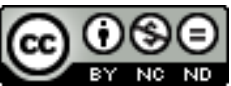

Ambiances is licensed under a Creative Commons Attribution-NonCommercial-NoDerivatives 4.0 International License. 


\title{
Staging Atmospheres: Editorial introduction to the second volume
}

\author{
Atmosphères en scène: Introduction au deuxième volume
}

Chloé Déchery and Martin Welton

\section{Scenography and the Sensible}

In their jointly authored study New Media Dramaturgy (2017), the Australian scholars Peter Eckersall, Helena Grehan and Edward Scheer use examples of performance works by Kris Verdonck, Olafur Eliasson and Nayaka Fujiko (amongst others) to identify and evaluate what they conceive to be an emerging 'theatre of atmospheres'. As well as involving or devising an 'aesthetics of participation', this ambient dramaturgy also rests on the design of 'material foundations' that enable 'sensory restriction, or dislocation' (2017, p.98). These are designs that seek to create both an energetics of affect as a mode of shared or public feeling, and a material encounter with elemental properties such as heat, light, or moisture. The elision of affects and elements that these designs afford and arrange for public perception is what lends them not only scenographic, but also dramaturgical force. This requires, on the one hand, shifting from a view of the former term as a matter of composing and manipulating 'stage pictures' towards an encounter with what Joslin McKinney describes as '[m]aterials acting on each other and in combination [to] produce a network of sensible matter of which the viewer can be part' $(2015$, p.123). On the other, 'dramaturgy' does not only (or even) imply the formal relations between a literary text and its staging, so much as it does the drawing together of space and movement in the composition of particular 'actions', whether those of theatrical events or of everyday life (Turner, 2015).

Certainly, insofar as this issue of Ambiances is concerned, with its thematic focus on 'staging atmospheres', scenographic and dramaturgical considerations cannot be left out of the account. However, notwithstanding the efforts of scholars such as McKinney and Turner to stress the extent to which scenographic and dramaturgical thinking need not be adumbrated by immediate concerns for staging, how such unavoidably 
theatrical concerns can - or, indeed, should - be applied beyond the events and institutions that conventionally contain them is a moot point. In this, it seems important to not only think about the application of theatre practice and its critical frameworks within other contexts, but also the degree to which that practice and critique participate in the rejuvenation of the aesthetic as an intellectual and ethical project discernible in other areas of enquiry, for which 'atmosphere' serves as an important heuristic.

\section{Corroding the Real}

If, as Bruno Latour has suggested an 'aesthetic' perception or practice can be taken to mean a "capacity to "perceive" and to be "concerned" - in other words, a capacity to make oneself sensitive' (2017, p.145), then theatre must surely provide environments and practices in which this can occur. From the earliest shadow plays, through perspectival design, to Verdonk's 'strategy of staging natural phenomena by enclosing it in contained spaces' (Manuel, 2017, p.70) theatre could be argued to be a nonpareil social and artistic form in the development of the perception of, and concern for, atmospheric conditions. For Latour, the aesthetic sensitivity he sets out is a crucial mode of attention for engagement with what he terms 'the new climatic regime' in which theatre must be thought to have a role to play in tuning the capacities of its artists and audiences to the accelerating crisis of climate. Similarly, French philosopher Baptiste Morizot (2020) has analysed what he calls the 'crisis of the sensitive' that we are currently experiencing as the direct manifestation of the disconnect between human modes of existence and other non-human living experiences, or, in other words, of an 'impoverishment of what we are able to sense, to perceive, to understand and weave in within our relations to other living beings. A reducing of the range of affects, perceptions, concepts and practices that ties us in to the living' (2020, p.17).

It has often be claimed that artistic creation (amongst varied forms of descriptive or speculative languages such as botanics, or ethology) can provide the possibility of designing new experiential or relational models that would help rekindle those relationships between living beings. ${ }^{1}$ It is notable however, that ecocritical studies, even when examining practices of staging or performance - and whilst having informed art history, cinema or contemporary art - have largely eschewed the theatrical. Where the rhythm and logic of the ecocritical is rooted in crisis and urgency, the theatrical has often been perceived to be non-urgent or even an indulgent distraction and quintessentially 'unreal' in a manner that is unhelpful in terms of addressing the environmental catastrophe unfolding in real terms (Arons \& May, 2014). of what use then, are theatrical atmospheres in engaging the kinds of ecological questions posed by Latour for 'new climatic regime': 'Where do we reside? What type of territory, ground, space, or place are we apt to inhabit, and with whom are we ready to cohabit? In what epoch do we find ourselves - not in terms of the calendar but, rather, in terms of the rhythm, the scansion, the movement of time?' (2017, p.39).

5 However, bemoaning the probable poverty of an address to these questions in terms of acts or activism risks perpetuating a peculiar, yet enduring line of thinking, that theatrical events should service some sort of enhanced transaction with 'reality' in either form or substance. Rather, we would suggest, as Carl Lavery has argued, that 'the most -or maybe best - that one can hope to achieve is to produce a theatre that 
highlights its own incapacity to signify, its own failure to act' $(2019, \mathrm{p} .4)$. This is an aesthetics that seeks to 'corrode' rather than affirm or produce the real, sensitizing us to otherness, rather than the actual. Across the articles in the issue, we encounter atmospheric stagings that offer attunements to affects, environments, and sensations as acts of engagement, rather than representation.

\section{Shifting Our Sightlines}

6 This reattunement often means setting aside a notion of theatrical space as one that is necessarily organised in relation to 'sight lines', those imagined visual axes between a spectatorial point of view and the objects of interest before them on stage. As Martin Jay has noted, the presumption of the unwavering and idealised gaze of a 'sovereign eye' not only embeds certain ideological notions within the social and physical architectures of theatre, but also perpetuates the bizarre ontology of a sensorium in which vision is modelled as both disembodied and dissociated from other sensory modalities. The apotheosis of the ordering of sightlines is found in the vanishing point of renaissance perspective in which Jay locates not only 'an externalized eye above temporal duration' but also a perceptual disconnect between 'viewer and viewed...as the spectator withdrew entirely from the seen (the scene)' (1993, p.55). For Jay, paraphrasing J.J. Gibson this set the scene for an intellectual culture in which 'the visual field now replaced the visual world' (ibid.). The advent of differential lighting states between stage and auditorium in the mid-nineteenth century can only have served to underline this further, with the disappearance, under darkness, of one's own, and other bodies from this visual world. Indeed, we suggest, the power of the trope of the visual field has not only been to off-set its worldly other, but also to displace seeing from the rest of the sensorium. This is testified to by not only the enduring strength of the vernacular deferral to vision in the expression 'going to see a show', but also in the extent to which ideas of sensorial redress have become central to efforts to account for the aesthetics of so-called immersive performances through such descriptions as 'visceral physical expression' (Westling, 2020, p.51) and a 'kind of emotional/visceral/ multisensory experience' (Biggin, 2017, p.3). Such invocations of performances that play out for (or upon) the audience's bodily organs, rather than within a disembodied visual field organised around the sightlines of an imagined spectator, testify to a desire to engage a more expansive sensorium in both the practice and critique of contemporary theatre. The irony of this, however, is that such performances are often produced with highly visual aesthetics - the extreme level of detail in the design of benchmark performances such as Punchdrunk's 2007-2008 The Masque of the Red Death and YouYouMeBumBumTrain's eponymous 2004-2016 production perhaps providing cases in point.

7 A greater reconfiguration of both sensorium and space might be found in those contemporary performances that do not so much seek visual immersion as they do the displacement or othering of the spectator as a 'seer' altogether. As Rachel Hann notes in this issue, to do so invites a readdressing of conceptual and phenomenological categorisations of space as being experienced from its boundaries. Performances that shift their terms of engagement beyond the appearance of visually determined space, she proposes, create an atmospheric aesthetics that blurs scenographic and worldly experience. These are atmospheres that she describes in terms of a participatory 
experience of the feeling of possibilities - in this instance the British Grime artist Stormzy's performance at the 2019 Glastonbury Festival.

8 For all that theatre has been lauded as an art of shared experience, the frequent paucity of its delivery of this as a meaningful aesthetic beyond mere gathering has been painfully underlined by the COVID-19 pandemic. Not only were theatres shut down during this period, but their very nature as spaces of public gathering appeared either threatening or unappealing. The formal relation between place (or space) and seeing maintained from the Greek theatron up until then has since seemed, if not broken, then diminished. During the pandemic and the numerous resulting lockdowns, the very notion of the 'public' has equally been challenged. With the impossibility for citizens to gather in a shared space and exchange ideas and affects, we have also witnessed how the very existence of a collective political body (a community, a nation) can be weakened. As a result, there is an urgency in not only addressing the world through theatrical representation, but also in finding or engaging the world within it. Although such experimental approaches certainly existed well before the pandemic, there was real innovation in the extent to which theatre artists sought to enable 'multiple worlds' in Hann's terms, in which affective atmospheres are the property of both quotidian and aesthetic experiences. These might include Silvia Mercuriali's Swimming Home, which invited participants to don swimming suits and goggles, and listen and make use of a sound-based app to stage a performance in their bathroom; Darkfield Radio's Visitors, an 'immersive audio experience' for two people listening together, whilst sitting opposite one another in their living room'; or Cyclical, by theatre-maker Michael Pinchbeck which offered 15 minutes of remote participation and insight into the bicycle journey that would have taken him between his home town (Nottingham) and the one he works in (Manchester) had there not been lockdown. ${ }^{2}$

9 This bleed of the staged and the quotidian was also to be found as theatres themselves began to reopen. One of the first performances in London immediately after the first period of lockdown was an adaptation of José Saramago's novel Blindness at the Donmar Warehouse. Leaving aside the obvious and unsettling parallels between Saramago's story of a society collapsing in the face of an unexplained plague and our own tenuous condition, the production was noteworthy for being presented in part through the playback of a binaural recording during which the audience were frequently moved from brilliant light into total darkness, before, in a moment of respite and hope at the end, the giant scene-dock doors were opened to the street outside. Where scenographic and dramaturgical practices might sometimes be conceived as techniques for establishing distinctions between 'here and there', and 'then and now', these movements of air, sound and light served instead to confuse and corrode them. Elsewhere, in Paris, during the festival d'Automne in 2020, the Swiss director Milo Rau presented Familie, a theatre performance based on a real life event of a family of four committing suicide in the outskirts of Coulogne, in the North of France in 2007. In the performance, spectators were invited to peer into the family's house through entirely transparent glass wall, helped by a multimedia set-up that allowed them to see angles and corners that were not otherwise accessible. The feeling of suffocation and isolation that was a common experience shared by many during the first lockdown in Spring 2020 was here rendered through compelling scenography that blurred together the inside and the outside, the public and the private. 
10 Rather than attempting what Lavery (2019, p.4) terms the 'Promethean' effort of holding the world at bay, these performances wilfully accepted its presence. Accordingly, aesthetic atmospheres produced within them have a 'reality', not because they resemble or copy such conditions, but because they are at play with them. Indeed, as Rachel Hann asserts in this issue, it is precisely because they invite us to blur oppositional categories (real/unreal, subjective/objective, matter/air, emotion/world), that theatrical atmospheres necessitate an idea of space that is always 'in process, in motion' in acts of sensory encounter. Hann sees a political potential for scenographic atmospheres in this, as the mutability of the 'non-binary' thinking they might foster invites shifted points of view beyond the 'orthodoxies of experience' perpetuated within the cultures of the Global North.

11 The political potential of shifts in spatial atmospheres is also explored by Leah Lovett in her consideration of the 'invisible theatre' developed by the renowned Brazilian theatre director Augusto Boal during the rule of the military junta in the 1970s. As Lovett notes, while 'invisible theatre' is widely acknowledged as one of the many interventions staged by Boal and his collaborators in his development of the theatre of the oppressed', 'it never functioned straightforwardly, as Boal claimed it did, according to the binary opposition of oppressor and oppressed (italics in original). Like Hann, Lovett not only sees a radical potential in the staging of atmospheres via their eschewing of binaries of experience, but also through them, the possibility to remediate space as an affective experience of self and surroundings. Invisible Theatre, in which actors initiate political discussions within the context of everyday circumstances (such as offering to work for food they are unable to pay for), is not simply an intervention within a space she proposes, but an opportunity for the re-articulation of structures of feeling that shape behavioural dispositions, and in so doing, the possibility of changing them. Perhaps especially when viewed within the context of the military dictatorships in Argentina and Brazil in which Boal's creative and political sensibilities were forged, spaces are always encountered in terms of atmosphere - in this case through oppression's disintegration of the self from the space you inhabit. There is a risk, of course that highlighting the structures of feeling that empower the subsumation of self and space also invites those who control power to either double down on, or re-invent them. As Lovett notes however, if we set aside the need for creative approaches to atmosphere to be immediately efficacious, even subtle interventions have the potential to 'render structures of feeling visible' and in making them sensible, alter the conditions of their experience thereafter - a potential for change if not change itself. A notable element of Boal's theatre practice and its political legacy has been the unsettling of actors and their spectators as distinct or readily identifiable others. Whether an actor appears to be simply another member of the public in a restaurant (as in invisible theatre), or spectators are encouraged to take to the stage to enact dramaturgical and political alternatives to established narratives, as in Boal's better-known Forum Theatre approach, the promotion of agency with a newly indeterminate atmosphere, is both a temporary and/or possible release from one that was previously oppressive, and a redress of space and subjecthood accordingly.

12 Although the political stakes are radically (if not altogether) different, this blurring of self, space, and staging is also central to the atmospheres discussed in Maxime Le Calve's study of Jonathan Meese's production of a Virtual Reality (VR) artwork Mother and Son: Reality versus Art (The A.V.E.N.I.R. of Infinity). As Le Calve notes, since the early 
days of VR, the total or immersive involvement in a world view that it appears to present has often led commentators to make comparison to Wagner's notion of the Gesamtkunstwerk or 'total artwork'. In its most iconic forms Matthew Wilson Smith suggests, 'while it seeks to bury all outward signs of mechanical production' the Gesamtkunstwerk 'nevertheless relies heavily on mechanization for its pseudoorganic effects' (2007, p.3). Similarly, while the 'total' perspective VR seems to offer also serves to 'hide the wiring', in doing so, it seems, oddly, to reinforce its own alterity. Certainly, the 'total' nature of these effects seems rarely to be as complete as their evangelists would have us believe. VR is still as apt to be disrupted by 'noises-off' as a show in a conventional theatre, and any such state of immersion it might achieve is always established through a set of viewing conditions (a headset and glove, a gaming or gallery context) that delimit it as an event from the more total conditions of reality per se. For many theatre scholars these disadvantageous relations to 'real life' are all too familiar. However, as these colleagues might well wish to argue, whether or not VR manages to obscure, represent, or otherwise repudiate 'real life' through the totality of its conditions, to fixate on this is precisely to reassume the Promethean desire for perspectives beyond those of lived experience critiqued by Lavery. One of the intellectual and aesthetic inroads forged in the turn to a 'postdramatic' model of theatrical performance over the last thirty years or so (Lehmann, 2008) has been a dramaturgy of relations in which meaning is not given, but is uncovered in perceptual movements by and amongst the bodies of audiences. Certainly, in aesthetic terms these motile relations recall the sensitivity to and concern for the rhythm and movement of living that Latour suggests are necessary to any address to the 'new climatic regime'. Even if they do not address ecological calamity in an immediate or activist sense, then the elision of the locative 'where' of space with a practical address to 'how' to apprehend it in practice that they set out, is at the very least the beginning of an attention to the lived experience of 'worlding' that Latour, following Donna Haraway (2008) proposes as a necessary revision to the impasse of spatial and ecological abstractions such as 'the local' and 'the global'.

13 Although he does not address questions of climate or ecology, the matter of 'worlding' is central to Le Calve's article, in both the subject and method of its research. Meese's VR artwork, he suggests, is an effort 'to elicit and capture an atmosphere to make it perceptible to a distant viewer in time and space'. While it cannot ever hope to deliver a 'world' as such, by seeking to stage and make atmospheric conditions perceptible, there is more than simply the (re)production or instilling of affect at stake. As Derek McCormack has argued, it is wrong to consider atmospheres as 'only emotional phenomena' (2018, p.11) and leave out the 'meteorological' ways in which our lives are enveloped, condensed, or precipitated affectively. 'Seen thus', he proposes, atmosphere is the name given to 'an elemental condition in which bodies are enveloped. It's spatiotemporality is not only meteorological in a climatological sense but also because it shapes sense of feeling or being enveloped in a process akin to an ongoing precipitation of percepts and affects' (2018, p.21). Le Calve's ethnographic account of the production of Meese's Mother and Son uses both written description and drawings to set out both the process and precipitation of feeling that its chaine opératoire produces. By giving attention to the processes of production and the activities of those involved, Le Calve also usefully offsets any privileging of a subject-specific experience of the artwork in his ethnography, avoiding a reduction to 'either to the solipsistic subjective 
perception of the spectator' or 'that of an "aura" relative to the sole person of the artist'.

This offsetting of subjective privilege also informs Christian Edwardes' study of the artist's studio as a space of creative production, for which 'setting the scene' is both a metaphor and a means of atmospheric analysis. Edwardes deploys the notion of 'scene' to describe both scenographic arrangements of objects, points of view and so on, and as a tempo-spatial event. As an event, the place of production is afforded social and spatial reach beyond the bounds of a specific site, and the separation between the artwork and the work of art as a matter of labour and technical production becomes elided. Accordingly, not only is the haecceity of the artwork as an individual or unique object eroded, but the position of its viewer as that of a necessarily separate beholder is also brought into question. The art-historian Michael Fried famously accused theatricality of being 'the negation of art', as its constant need to defer to the position and presence of an attending audience 'reduces' the artwork to the mundane terms of their experience. For Fried, theatricality is a constant reminder of one's co-presence in time, and a degradation of the transcendent timelessness by which an artwork should distinguish itself from the everyday. In the atmospheric spaces described by Edwardes, the places and producst of artists' work merge and mingle with experiences of the everyday '“sites, spaces and processes' are characteristic of the life of the studio, and of art in life itself". The experience of these atmospheres is not simply (or even) the projection of the auratic presence of aesthetic objects within a scenographic space (the studio) but the staging of a 'meshwork' of relations in which 'they emerge as part of affective and contingent relations between human-non-human elements'. The studio as 'scene' is not limited to or fixed within a pictorial representation in Edwardes' account. The dust motes and physical effluvia in photographs of the ateliers of Giacometti, Pollock are not simply reminders of labour prior to the emergence of sculpted or painted things, but are also 'actors' whose co-presence serves to generate a 'recognition of apparently inconsequential moments of action that have a persistent affective resonance'.

The reappraisal of the 'apparently inconsequential' also features in Rebecca Collins' article 'Aural Attunement' in which she focuses on productive failures of language to capture or represent the complex vitality of non-human (in this case avian) life. In Emma Bennett's performance Slideshow Birdshow, Collins finds a productive failure of language to describe or categorise avian life. Instead, she argues, the collapse of descriptive language into stutters, cries, and pulses produces an atmospherics of tone, vibration and rhythm that serves as a sensorial attunement to the nonhuman. Like other authors in this issue, Collins finds this atmospheric attunement not simply a relational aesthetic (one to another), but a spatial one - as Andreas Rauh notes: 'the sphere of language is more than just a formal medium, but an audible quality of the surroundings itself' (2018, p.77). The chirruping hiccups that Bennett produces in her efforts to describe different birds 'fail' as language in some fundamental sense of communication, but insofar as they create swirls, eddies and pulses of sound that give a dynamic form to space, they offer those listening an experience in-kind that exceeds the relational terms of listener and listened-to. Sounding and re-sounding, this is a sensing of surroundings as well as subjects, of space as an unfolding situation, rather than a static arrangement of surfaces and edges. What Bennett's performance 'attunes' is an attention to these dynamic spatial properties, and: 'to our capacity to spend time 
in the moment of perception without feeling the urgent necessity to classify, or name, what is being perceived'.

Attunement also features as a key strategy within Philippe's Quesne's staging, as analysed in Zoe Brioude's article. 'Attunement' here refers to an attention to the very conditions of possibility of what can constitute an 'atmosphere' on stage, a concern that is central to both the Quesne's aesthetics and the construction of personae as enacted by the performers on stage. No plot or character development arise within Quesne's theatre, and in his 'theatre of matter', drama gives way to the staging of micro-elements constantly re-assembling themselves, including events that occur when air turns into mist or water turns into snow under the weight of temperature and other controlled climate conditions. In some respects, the quality of attention or attunement that is demanded from the spectator and which brings into focus the micro-transformations of the material world, could be described as 'idiotic', in the way philosopher Clément Rosset (1977) intends it as he unfolds the etymology of the term (simple, singular, unique). Within these atmospherics that progressively emerge as 'worldings' and where nature is not apprehended as a decorative backdrop but is fully acknowledged as an integral part of a 'milieu', the spectator experiences the possibility of another way of being in the world, plainly attentive and implicated as the witness of more or less dramatic climate, meteorological and material changes and transformations that do not stand for anything else than themselves. Thus, an attunement to 'idiotic' attention, as exemplified by Quesne's peculiar persona, could also be seen as an ethos for spectatorship; a way of negotiating what is to be perceived as inherently subject to mystery, thus leading us, spectators, to experience other forms of weakness and semi-ignorance.

Yves Citton notes a distinctive quality in the verbal treatment of 'attention' in French in comparison to some other European languages: 'the peculiar feature of situating attention in the situation of a particular kind of doing [faire]' (2017, p.171). In English, by contrast, attention is something that is paid - given, lent or expended upon its object. As much as this may speak to an underlying capitalist animus in the AngloSaxon condition, the French faire attention at least 'carries its own benefit with it' as a practice that 'constitutes its own end' (p.171). Similarly, Collins' own listening to and re-languaging of Bennett's performance has something of this same autotelic quality. It is one that, in her rendering of it, seeks to 'grasp an essence of the performative and affective aspects of 'what happens' in the moment of perception'. 'What happens', she proposes, is grasped sensorially, rather than in comparative mappings of categories, and demands a certain sort of 'lingering' with phenomena that are often elusive. The 'doing' of attention that such acts as 'lingering', 'grasping' or 'turning towards' that Collin's evokes, points to the motility at the heart of atmospheric experience - of moving and being moved with and within currents and intensities that form and inform but exceed one's own subjective experience. As Friedlind Riedel puts it: '[c]ircumventing the clause of subjectivity characteristic of Böhme's notion of atmosphere, a focus on movement in which bodies are continuous with architecture, sound, or climate...enables a study of atmosphere that decenters the human being' (2019, p.93). This decentering of human subjectivity by and within atmospheric movement points again to an ecological sensibility that Lavery $(2019$, p.5) schematises as 'weakness', an undoing of notions of mastery and purpose in which theatre and nature alike reveal themselves for human comprehension. 


\section{BIBLIOGRAPHY}

Aït-Touati, Frédérique \& Coccia, Emanuele (eds.). 2020. Le Cri de Gaïa. Penser la Terre avec Bruno Latour. Paris: La Découverte.

Arons, Wendy \& May, Theresa J. (eds.). 2012. Readings in Performance and Ecology. Basingstoke: Palgrave Macmillan.

Biggin, Rose. 2017. Immersive Theatre and Audience Experience: Space, Game and Story in the Work of Punchdrunk. Basingstoke: Palgrave Macmillan.

Citton, Yves. 2017. The Ecology of Attention. London: Polity.

Coccia, Emanuele. 2019. Le semeur, De la nature contemporaine. Arles: Fondation Vincent Van Gogh Arles.

Eckersall, Peter; Grehan, Helena \& Scheer, Edward. 2017. New Media Dramaturgy: Performance, media and new-materialism. Basingstoke: Palgrave MacMillan.

Fried, Michael. 1998. Art and Objecthood: Essays and reviews. Chicago: University of Chicago Press. Haraway, Donna. 2008. Companion species, mis-recognition, and queer worlding. In: Giffney, Noreen \& Hird, Myra J. (eds.). Queering the non/human. London: Ashgate, p. XXIII-XXXVI.

Jay, Martin. 1993. Downcast Eyes. Berkley: University of California Press.

Latour, Bruno. 2017. Facing Gaia: Eight lectures on the new climatic regime. Oxford: John Wiley.

Lavery, Carl (ed.). 2019. Performance and Ecology: What Can Theatre Do?. London: Routledge.

Lehmann, Hans Thies. 1999. Postdramatic Theatre. London: Routledge.

Manuel, P.A.C.R. 2017. Theatre Without Actors: Rehearsing New Modes of co-Presence [online]. PhD thesis. Utrecht: Utrecht University. Available online at: https://dspace.library.uu.nl/handle/ 1874/358079 (consulted December 3, 2021).

McCormack, Derek P. 2018. Atmospheric Things: On the Allure of Elemental Envelopment. Durham: Duke University Press.

McKinney, Joslin. 2015. Vibrant materials: the agency of things in the context of scenography. In: Bleeker, Maaike; Foley Sherman, Jon \& Nedelkopoulou, Eirini (eds.). Performance and Phenomenology. London: Routledge, p. 131-149.

Morizot, Baptiste. 2020. Manières d'être vivant. [trans. C. Déchery]. Arles: Actes Sud.

Rauh, Andreas. 2018. Concerning Astonishing Atmospheres: Aisthesis, aura and atmospheric portfolio. Milan: Mimesis International.

Riedel, Friedlind. 2019. Atmosphere. In: Slaby, Jan \& von Scheve, Christian (eds.). Affective Societies: Key Concepts. London: Routledge. p. 85-95.

Rosset, Clément. 1977. Le Réel : Traité de l'idiotie. Paris: Éditions de Minuit.

Turner, Cathy. 2015. Dramaturgy and Architecture: Theatre, utopia and the built environment. Basingstoke: Palgrave MacMillan.

Westling, Carina E. I. 2020. Immersion and Participation in Punchdrunk's Theatrical Worlds. London: Bloomsbury. 
Wilson Smith, Matthew. 2007. The Total Work of Art: From Bayreuth to Cyberspace. London: Routledge.

Zhong, Estelle. 2020. Apprendre à voir, le point de vue du vivant. Arles: Actes Sud.

\section{NOTES}

1. For further discussion see also: Coccia (2019); Zhong (2020); Aït-Touati and Coccia (2020).

2. https://homemcr.org/production/cyclical/

\section{ABSTRACTS}

In this second special issue of Ambiances on Staging Atmospheres, we return to the material and metaphorical felicity by which theatrical performance, design and their reception, present themselves to critical and political thinking in relation to atmosphere. We note, amongst other factors, the particular significance of scenography - at once an intellectual and aesthetic concern - in providing a framework by which to consider the material presence of atmospheres within theatrical events themselves, and by extension, in quotidian and other milieux beyond them. Moreover, we consider how, across the considerable range of examples offered by our contributors, the heuristic of staging is released from a somewhat moribund connection to the 'stage set' and instead becomes a process of lived encounters with the affects and affordances of social and material environments.

Dans ce deuxième numéro spécial d'Ambiances sur la mise en scène des atmosphères, nous revenons sur la félicité matérielle et métaphorique par laquelle la performance et la scénographie théâtrales ainsi que leur réception se présentent à la pensée critique et politique en relation avec la question de l'atmosphère. Nous observons, parmi d'autres facteurs, l'importance particulière de la scénographie - une préoccupation à la fois intellectuelle et esthétique - qui fournit un cadre permettant de considérer la présence matérielle des atmosphères au sein des événements théâtraux eux-mêmes, et par extension, dans le quotidien et les autres mondes qui les dépassent. En outre, nous examinons comment, à travers l'éventail considérable d'exemples offerts par nos contributeur•trice•s, l'heuristique de la mise en scène est libérée d'un lien quelque peu moribond avec le "décor de scène » et devient plutôt un processus de rencontres vivantes avec les affects et les potentialités des environnements sociaux et matériels.

\section{INDEX}

Mots-clés: scénographie, dramaturgie, théâtralité, les sens, fragilité, spatialité

Keywords: scenography, dramaturgy, theatricality, senses, weakness, spatiality 


\section{AUTHORS}

\section{CHLOÉ DÉCHERY}

Chloé Déchery is a theatre-maker, performer and Lecturer in Theatre Studies at the University of Paris 8 Vincennes Saint-Denis in France. Her research interests include contemporary performance and corporality; politics of co-authorship; artistic labour in the neoliberal era; ecology and performance. She has a particular interest in practice-as-research, examining areas of intersection and cross-pollination between artistic practice and scholarly enquiry. She also works as an artist in performance and theatre, devising her own work collaboratively with artists coming from different disciplinary fields (choreography, music composition, dramaturgy). She is the co-leader of the research programme and curating platform Performer les Savoirs/ Performing Knowledge. www.chloedechery.com

\section{MARTIN WELTON}

Martin Welton is Reader in Theatre and Performance in the Department of Drama, Queen Mary University of London. His research centres on movement and the senses in the aesthetics of contemporary performance. With Adam Alston, he is the editor of Theatre in the Dark: Shadow, Gloom and Blackout in Contemporary Theatre (London: Bloomsbury, 2017). His monograph Feeling Theatre (2012) is published by Palgrave MacMillan. As well as published works, he also investigates sensory aesthetics in practice, in new theatre collaborations with professional artists outside the academy, most recently with RIFT theatre in 2018, in the AHRC-funded research project: Metamorphosis: Audiencing Atmospheres. 